\title{
Bounded Rationality and Voting Decisions Exploring a 160-Year Period
}

\author{
David Stadelmann and Benno Torgler ${ }^{*}$
}

\begin{abstract}
Using a natural voting experiment in Switzerland that encompasses a 160 -year period (1848-2009), we investigate whether a higher level of complexity leads to increased reliance on expert knowledge. We find that when more referenda are held on the same day, constituents are more likely to refer to parliamentary recommendations in making their decisions. This finding holds true even when we narrow our focus to referenda with a relatively lower voter turnout on days on which more than one referendum was held. We also show that when constituents face a higher level of complexity, they listen to parliament rather than interest groups.
\end{abstract}

Keywords: Bounded rationality, voting, referenda attention, rules of thumb

JEL Classification: D03, D72, D83, H70

* David Stadelmann, University of Fribourg, Department of Economics, Bd. de Pérolles 90, 1700 Fribourg, Switzerland, david.stadelmann@unifr.ch. Benno Torgler, School of Economics and Finance, Queensland University of Technology, GPO Box 2434, Brisbane, QLD 4001, Australia, and EBS Universität für Wirtschaft und Recht, ISBS, EBS Business School, Rheingaustraße 1, 65375 Oestrich-Winkel, Germany, benno.torgler@qut.edu.au. Both are also affiliated with CREMA - Center for Research in Economics, Management and the Arts, Switzerland. We thank William Baumol, Bruno Frey, Reiner Eichenberger, Geoffrey Hodgson, Simon Lapointe Marco Portmann, and Nadia Yerly for very helpful and encouraging comments. We acknowledge financial support from the Australian Research Council (FT110100463). 
Viewed as a geometric figure, the ant's path is irregular, complex, hard to describe. But its complexity is really a complexity in the surface of the beach, not a complexity in the ant.

(Herbert A. Simon 1957, p. 51)

When many problems demand concentrated attention at once-and this is always happening in modern industrial society —reliance on the expert specialist is the only resource.

(John Maurice Clark 1918, p. 28)

\section{INTRODUCTION}

As part of its recently revived commitment to correctly describing or prescribing human economic affairs, economics has been aiming to achieve a single, widely-accepted, and precise behavioral theory of choice. Simultaneously, there has been an increased interest in economics in working with the idea that human rationality is bounded and thus theories building around more realistic models of human actors. As pointed out by Herbert Simon, a pioneer of this concept (Simon 1955, 1956), the idea that human rationality is bounded by limitations has persisted from classical until modern times. Simon (2000), for example, cites Voltaire's statement in his Dictionaire Philosophique that "the best is the enemy of the good" and points out that "in modern translation: "optimizing is the enemy of satisficing", (p. 26). In earlier work, Simon (1957) defines the principle of bounded rationality as follows: "The capacity of the human mind for formulating and solving complex problems is very small compared with the size of the problems whose solution is required for objectively rational behavior in the real world-or even for a reasonable approximation to such objective rationality" (p. 158).

Almost a century ago, John Maurice Clark (1918) (son of John Bates Clark) put forward interesting ideas about decision-making that are consistent with the concept of bounded rationality and satisfaction. Most particularly, Clark stresses that decision making involves an attention effort that cannot be sustained for long time because of limited cognitive capacity. He links his discussion to works like Cooley's Human Nature and Social Order, which refers to the human tendency toward "protecting ourselves by some sort of mechanical control-

${ }^{1}$ Simon (1957) coined the term "satisficing" replacing it with the goal of maximizing through finding strategies or actions that are good enough. He argues that "organisms adapt well enough to 'satisfice'; they do not, in general, 'optimize"' (Simon 1956, p. 129). 
some accepted personal authority, some local custom, some professional tradition, or the like. Indeed, to know where and how to narrow the activity of the will in order to preserve its tone and vigor for its most essential functions, is a great part of knowing how to live. An incontinent exercise of choice wears people out, so that many break down and yield even essentials to discipline and authority" (as cited in Clark 1918, p. 23). Clark also stresses that a "good hedonist would stop calculating when it seemed likely to involve more trouble than it was worth, and, as he could not in the nature of the case tell just when this point has been reached, he would make no claim to exactness for his results" (p. 25).

Clark's observations describe the avenue of our endeavor: to investigate whether a higher level of complexity leads to an increased reliance on simple rules of thumb. Specifically, we explore whether humans rely on the expert specialist as a rule of thumb when many problems demand concentrated attention simultaneously, a topic on which, to our surprise, there is little empirical evidence. A valid empirical identification of whether humans follow rules of thumb as a consequence of bounded rationality requires that (1) the variable employed in their decisions is objectively measurable, (2) the decision itself is relative simple (ideally dichotomous), inexpensive and frequently repeated, and (3) the rule is applied in a complex environment. We study a natural experiment in voting across a period of 160 years (1848-2009) which fulfills all these requirements.

In Switzerland-whose institutional environment has been stable since 1848-we analyze constituent voting behavior using parliament as the expert specialist. We assume this perception of expertise because in most modern democracies, the set of experts to which the division of labor delegates the information-provider function includes politicians, interest groups, the government, and/or professional information gatherers (Downs 1957). This assumption is further supported by Grönlund and Setälä's (2007) analysis of European Social Survey (2002-2003) data, which finds that citizens in the Nordic countries, Switzerland, and Luxembourg report the highest levels of trust in their national parliaments and have the highest level of overall trust in political institutions. We therefore assume that parliament, as a collective source of wisdom, may be more credible than a single politician. Citizens acquire political information to help them decide how to vote. In Switzerland, the parliament always offers an ex ante voting recommendation for referenda, a standard method of information provision that enhances its image as expert consultant. We identify the effect of these public parliamentary voting recommendations on constituents' real choices (i.e., the revealed preferences of both the constituents and parliament). Such voting decisions are influenced by the actions of leaders, who provide help through informing voters about the issues (Shachar 
and Nalebuff 1999). Thus, the variable employed in the decision, i.e. parliament's recommendation, is observable and measurable. Moreover, referendum decisions represent constituents with dichotomous choices which are inexpensive and frequently repeated adding up to a total of 555 voting decisions thereby fulfilling a further central requirement of a valid identification of the use of rules of thumb.

Most particularly, we use two ways of identifying complexity comparable to an experimental setting that demands concentrated attention on several simple issues simultaneously. First, to ensure careful selection of theoretically relevant behavior measures, in constructing our dataset, we recognize that although parliament may always influence constituent decision making somewhat, from our theoretical perspective, this influence is likely to be larger when the number of referenda is higher than one, i.e. the rule of thumb is more frequently used when more referenda are held. In Switzerland specifically, every referendum is preceded by an open public discussion; however, such a discussion is easier for constituents to follow if they need only decide on a single issue and their attention is not divided between two or more issues on the same day. Our setting allows us to distinguish between days on which there is only one referendum and days on which two or more referenda take place. If constituents follow a rule of thumb, we predict that when more referenda are held on the same day, they will be more likely to refer to outside recommendations in their decision-making. We therefore use the number of referenda per day as a first measure of complexity to identify parliamentary influence on constituents' choices.

Second, to further pinpoint this influence, determine whether constituents are bounded in their rationality and therefore employ rules of thumb, we focus only on days with two or more referenda. Because of systematic voter registration in Switzerland since 1884, we know the number of voters and also the number of valid votes in referenda. We therefore know how high the turnout was for all referenda. As constituents incur the same costs for voting in the first referendum as for the second or third on a given day, we can use differences in turnout within constituencies to identify which referendum on a given day attracted the most attention. In particular, because even individuals that go to the polls do not necessarily vote on all ballot issues (Crain, Leavens, and Abbot 1987), we identify the referendum with the highest turnout of the day. Recognizing that constituents are more likely to cast a vote for a referendum about which they are better informed, while some with little information may still vote but rely more on parliamentary recommendation, we identify the parliamentary influence by focusing on referenda with a relatively lower turnout on days on which more 
than one referendum was held. The strength of this empirical design is that we can use the percentage of voter turnout to directly identify the voters' focus of attention.

The article proceeds as follows: the next section provides a deeper discussion of this methodology. Section III describes the data setting and identification strategy. Section IV presents the empirical results, and Section V concludes.

\section{BOUNDED RATIONALITY}

Economists' increasing interest in bounded rationality is reflected in the fact that $44 \%$ of the 825 articles published on this topic between 1996 and 2012 appear in economics journals. ${ }^{2}$ Moreover, there has been also been an increased interest in economics in working with theories of more realistic models of human behavior that in Simon's (2000) words "avoid over-simplification where it makes a consequential difference" (p. 30). Most particularly, Simon (1992) claims that "to omit from economic theory a consideration of human computational power is like omitting gravitational forces from astrophysical theory. In a weightless world, or one with gravity shields, things would be quite different from the way they are in the actual world. A theory for the former would have little predictive value in the latter" (p. 26).

The research agenda, therefore, is to go beyond Milton Friedman's (1953) assertion that a theory cannot be judged by the realism of its assumptions but only by its efficacy in making predictions. ${ }^{3}$ Neoclassical theory, Simon (1992) argues, is flawed in having no notable record of correct predictions and, even where success has been claimed, a paucity of comparisons with alternative theories. ${ }^{4}$ It is also unclear why unrealism is acceptable: "Among the inferences that can be drawn from any theory, hence among its predictions, is the truth of its assumptions. A theory can be falsified by falsifying its axioms as readily as it can be falsified by falsifying any of the theorems that can be derived from the axioms. There is no support in any system of logic with which I am familiar, or in any school of philosophy of science, for Friedman's principle of unrealism" (p. 36). Friedman's error, Simon contends, may be attributed to confusion between unrealism and approximation, a confusion he illustrates using

2 ISI Web of Knowledge on March 30 (2012).

${ }^{3}$ See also Conlisk (1996) for a discussion of prominent arguments in favour of unbounded rationality.

${ }^{4}$ In their eye-tracking study, Reutskaja et al. (2011) use an experimental design that is comparable to consumer decisions in a modern supermarket. This design allows comparison of the efficacy of three alternative dynamic search models: an optimal dynamic search with zero search costs, a satisficing model, and a hybrid model in which subjects search for a random amount of time dependent on the value of the goods seen and make the "best" choice. They conclude that the hybrid model performs best. 
Friedman's example of Galileo neglecting air resistance when stating the law of falling bodies: “.... air resistance can be ignored when studying the fall of bodies in a near-vacuum, but not when designing parachutes. And in no case does a theory of approximation support the principle of unrealism, that it doesn't matter if the premises of a theory are false. Unrealism is no virtue, and unless careful attention is given to the goodness of approximation that is required, it can be fatal" (p. 37).

It is therefore not surprising that bounded rationality has become more dominant in recent years. For example, in a revised version of the Nobel lecture delivered in Stockholm on December 8, 2002, Kahneman (2003) explains that his research team was attempting "to obtain a map of bounded rationality by exploring the systematic biases that separate the beliefs that people have and the choices assumed in rational-agent models" (p. 1449). Conlisk (1996) provides a nice overview of a large set of models that allow for bounded rationality. Baumol (2004), who attended the debate between Herbert Simon and Milton Friedman on the role of rational calculation in economic decisions, recalls the exchange: "Milton criticized that satisficing was just a form of camouflaged rationality, entailing a careful weighing of the costs of improved information and that of more sophisticated calculation, while Herb responded that this view dodged the substance of the issue, simply incorporating the one position into the other by terminological sleight of hand" (p. 58). These different lines of argument led to Baumol and Quandt's (1964) paper on the rationality of following rules of thumb, which leads to what they term "optimally imperfect decision making".

In the context of our paper, Simon (1986) claims that to "predict how a voter, even a voter motivated solely by concern for his or her economic well-being, will vote requires much more than assuming utility maximization... In any model of voting behavior that has any prospect of predicting behavior, almost all the action will lie in these auxiliary assumptions about attention and belief that define the decision maker's frame" (p. S217). Because our study analyzes the outcomes of different referenda on precisely the same day, we must take into account that people are endowed with a narrow capacity for simultaneous attention to different pieces of information (Simon 1983). In other words, humans can only deal with a limited number of problems at one time.

A key strength and advantage of our experimental context, therefore, is that we can observe the nature of the attention outcome using voter turnout over a very long period (160 years covering 555 referendum decisions) while still holding the setting (referenda) constant. While the changing shape of the decision-making environment may have influenced human goal-directed behavior over time (Simon 1996), our setting remains constant. Over the 160- 
year sample period, for example, citizens have grown up in very different social environments, with different knowledge, information, and social norms. Nonetheless, the same basic decision making rule is applied in complex situations which points to the identification of a common invariant of human behavior in decision making. To the best of our knowledge, there are as yet no studies that explore bounded rationality in such a real world setting over such a long time span.

Our natural experiment, we believe, is very well specified to derive empirical insights on the consequences of bounded rationality. Using voter turnout, we can directly measure which issue received more attention and offer a clear explanatory heuristic for the decision process mechanism. The limits of attention stem from people's inability to think about lot of things at the same time (Simon 1983). We can thus provide an answer not only on what decisions are made but also how they are made, thereby offering empirical evidence on procedural rationality and contributing to empirical knowledge on decision processes. Simon (1996) refers to such heuristic searching as a selective search using rules of thumb to find decisions that satisfice (p. 27) ${ }^{5}$.

To obtain a clear picture of how people vote, we postulate a simple heuristic mechanism enforced through habit and rule-governed behavior, one that can potentially identify the invariants of human behavior, particularly over a very long time span. In such a changing environment, adaptive individuals faced with complexity are likely to apply the same simple decision-making rules and habits, i.e. the essence is limited computational capacity in complex or extensive decision environment rather than just scarcity of cost information (Hodgson 1997). However, whereas Hodgson (1997) sees the problem of handling large amounts of information in terms of the net cost of obtaining it, in our case, extensiveness is less of an issue because parliamentary recommendations are readily visible in a booklet/pamphlet sent to voters prior to a referendum. In fact, since 1877 the federal council is required by law to issue information detailing the legislative proposal submitted. In other words, most of the information needed for decision making is simply placed into the voters' hands. On the other hand, complexity, which Hodgson defines as "the density of structural linkages and interactions between the parts of an interdependent system" (p. 669), is important for our study because individuals effectively have computational limitations when interpreting information received (Simon 1990). In fact, complexity in the cost function or

\footnotetext{
${ }^{5}$ For a detailed discussion on heuristics see Gigerenzer et al. (2011).
} 
other environmental constraints can be so great that bounded rationality becomes important as actors fail to calculate the best course of action (Simon 1972).

The challenge, therefore, lies in analyzing and using the information. Because the process of satisficing uses experience to construct an expectation of solution goodness (Simon 1990), while habit formation internalizes the decision process as an invariant of human behavior, introducing a model of satisficing behavior can greatly enhance understanding of how a decision or equilibrium is reached (Simon 1959).

We, in line with Clark (1918), argue that complexity produces a rule of thumb that constituents are more likely to follow parliamentary recommendations because parliament, being elected by constituents, is supposed to represent them and could be seen as experts. Voters may also believe that (in the aggregate) politicians and parliament as a whole act in the public's best interest. Hence, a rule of thumb that says "follow the recommendation of the parliament when complexity increases" is comprehensible. It also conforms to Simon's (1996) argument that "we should not look for great complexity in the laws governing human behavior, in situations where the behavior is truly simple and only its environment is complex" (p. 68). In fact, our empirical setting conforms to the central characteristics of a rule of thumb (see Baumol and Quandt 1964, p. 24). First, the variable employed in the decision-whether or not to follow parliaments' suggestion-is objectively measurable. Second, the decision is simple, inexpensive, and well suited to frequent repetition (i.e., frequent referenda among constituents). We therefore argue that when faced with information difficulties (a complex environment), constituents apply a simple decision-making rule.

\section{DATA SETTING AND IDENTIFICATION}

\section{Institutional Setting}

Switzerland's federal constitution, which dates back to 1848 , was basically modeled on the constitution of the United States. The Swiss parliament is made up of two houses, the National Council (Nationalrat), comparable to U.S. House of Representatives, and the Council of States (Ständerat), comparable to the U.S. Senate, and the parliamentary electoral districts comprise 26 constituencies (cantons or subnational jurisdictions). Switzerland's parliamentary system is one of direct democracy that, like over half of U.S. states, allows the holding of referenda. Not only may citizens from the different constituencies challenge any law that has been passed by parliament, but a referendum is always mandatory if a parliamentary legislative proposal aims to change the constitution. Citizens themselves may 
also demand a constitutional amendment by federal referendum/initiative, a request that cannot be refused by the government and parliament unless it violates formal rules (see Portmann et al. 2012 for details). Parliament can, however, work out a direct counterproposal, which is presented to the voters at the same time as the citizen-driven initiative. ${ }^{6}$

The results of a referendum, an instrument used constantly in Switzerland since 1848, not only determine policy outcomes, they also reflect citizen preference for these outcomes. More precisely, as pointed out by Schneider, Pommerehne, and Frey (1981) or Frey (1994), referenda permit the majority to rank the policy outcomes that will be generated by the proposed laws against the status quo. They thus present dichotomous results that indicate what a majority prefers and, consequently, what the median constituent prefers (see Frey 1994 or Eichenberger et al. 2012).

Figure 1, panel (a), summarizes the number of referenda per decade in our dataset from 1848 until the beginning of 2009. The ability to exploit such a large set of field data to identify revealed preferences and demonstrate how human problem solving and decision making takes place in a complex environment is a key strength of this paper. Since 1848, Swiss citizens have been presented with 520 unique federal referenda and 35 decisions with counterproposals, resulting in a total of 555 referenda. In terms of our dataset's time dimension, which spans three centuries, it is worth noting that 1848 is not very far away from 1789 when the U.S. Constitution became the basis for the United States federal government, only 12 years before Abraham Lincoln's election as President, and only 15 years before the Emancipation Proclamation freed slaves and gave them voting rights.

In issuing its voting recommendation for each referendum, the Swiss federal parliament naturally recommends acceptance for its own initiatives but usually suggests rejection for citizen-initiated referenda. Constituents for their part are generally well informed about parliamentary recommendations and the issues to be decided by referendum because of booklets/pamphlets sent out to voters before the election. This practice was formally initiated in 1877 when the federal council argued for giving constituents an official manifest that details the legislative proposal submitted for referendum. Parliament then entrusted the federal council with "officially and objectively informing citizens on the reasons for the referendum and how parliament formed its opinion" (translated from the German, see the appendix, Figure S1). As the federal council's address to parliament makes clear, even in the

${ }^{6}$ A counterproposal is usually designed to be a compromise between the current status quo and the demands in the initiative (see Stadelmann et al. 2012). We separately control for counterproposals in our empirical setting. 
decades before 1877 , voters were informed by the media about parliament's position, and as early as 1874, the federal council itself was officially disseminating such information (as stated in the Federal Gazette BBl 1874 I 497). Thus, even when voters did not necessarily fully understand the precise issue of a referendum, it can be expected that they did at least know parliament's position.

Figure 1: Total number of referenda and referendum days from 1848 to 2009

Panel (a): Total number of referenda

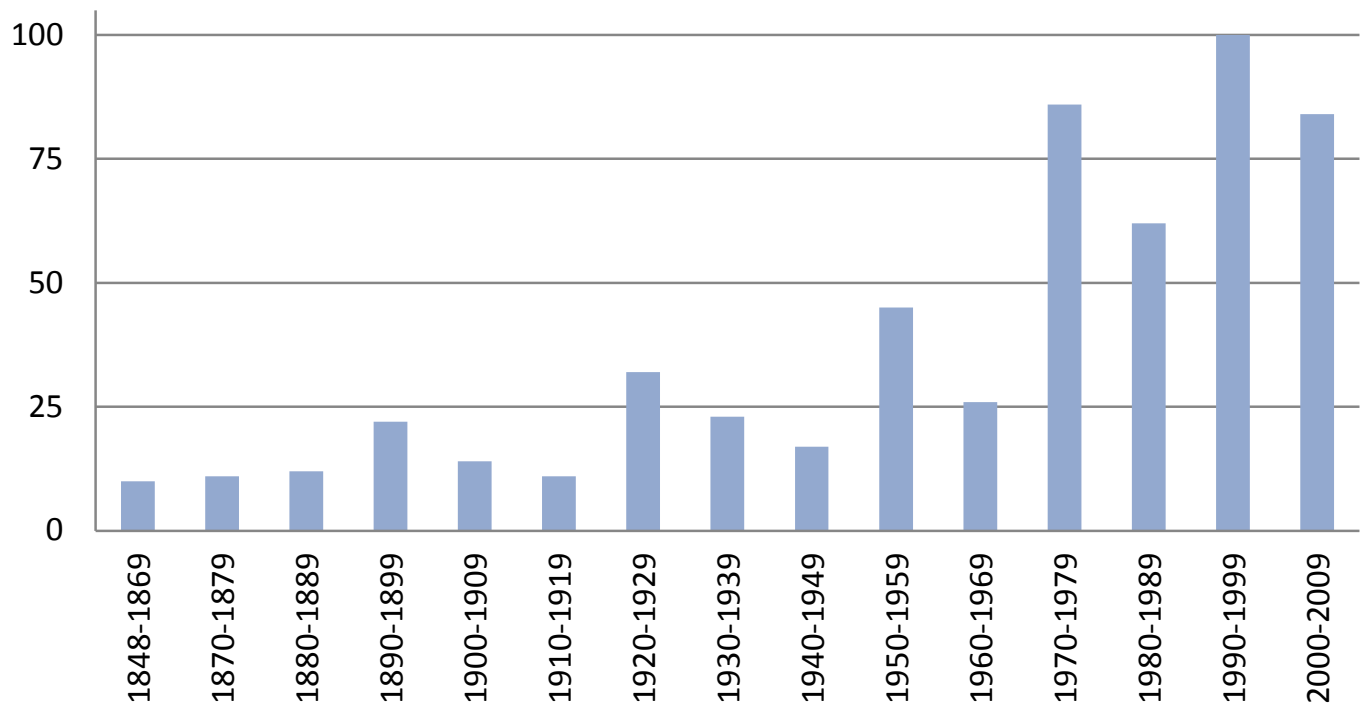

Panel (b): Average number of referenda per day

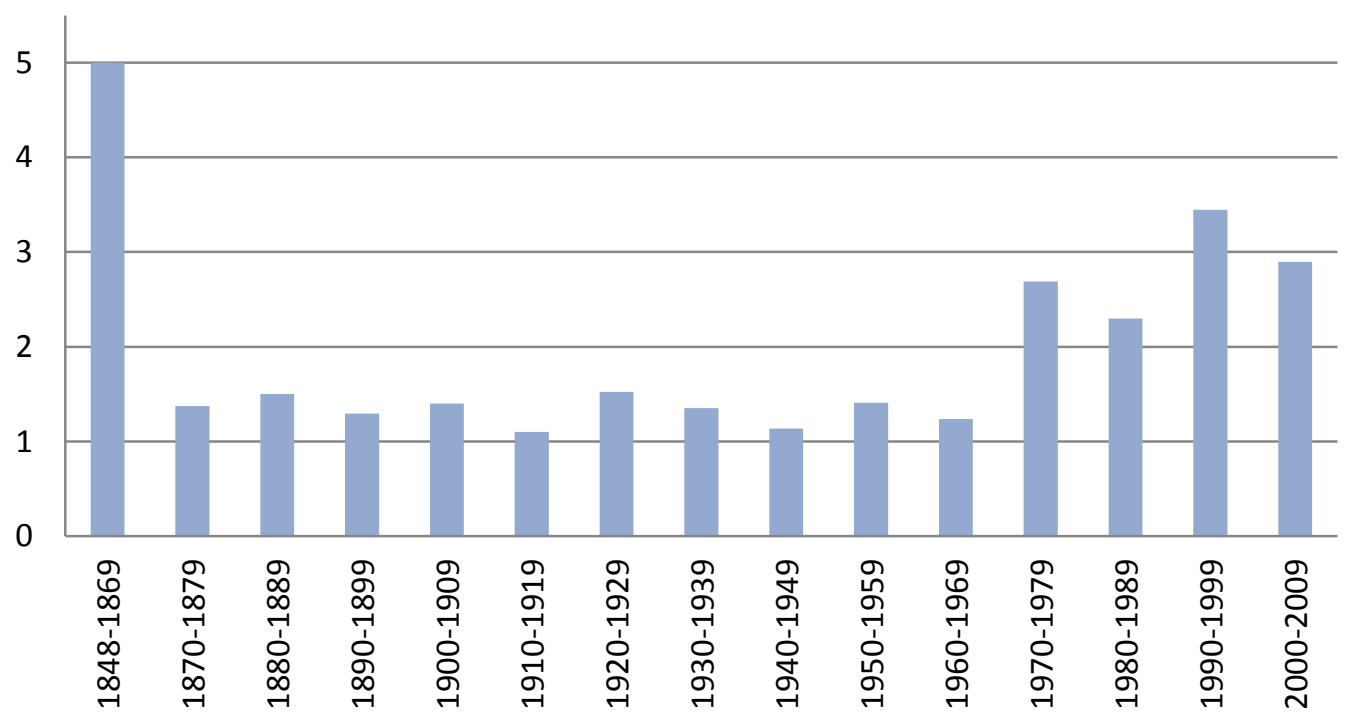

Notes: First referendum was held in 1848. 
Panel (a): from 1848 to 2009

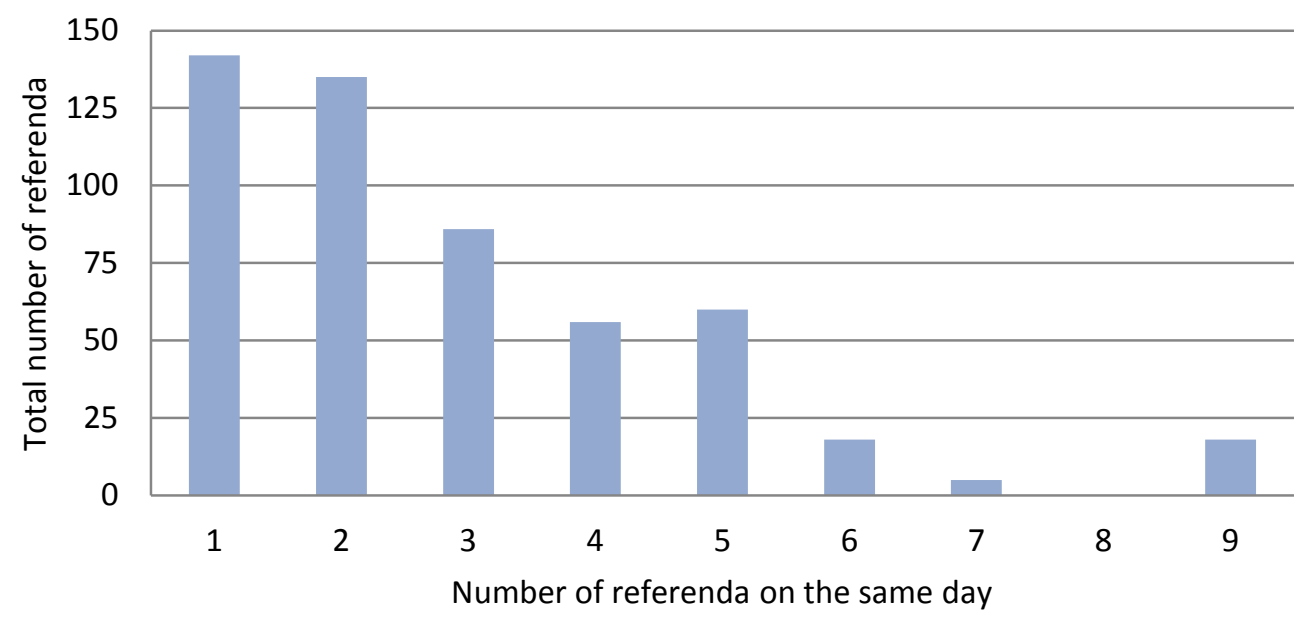

Panel (b): from 1848 to 1945

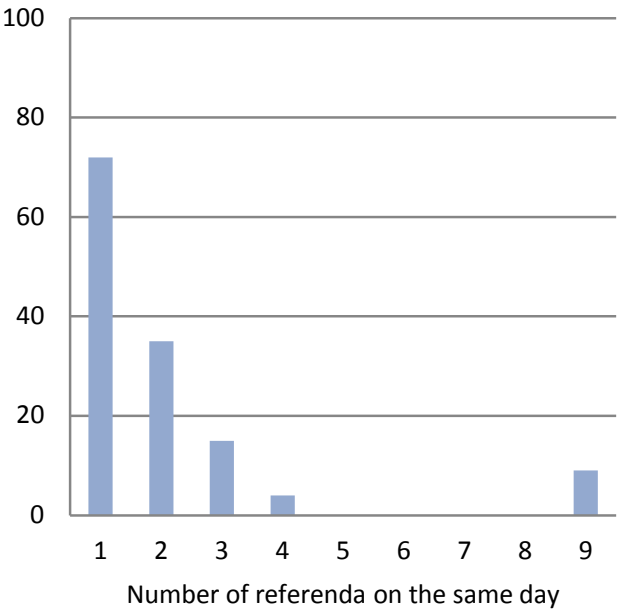

Panel (c): from 1946 to 2009

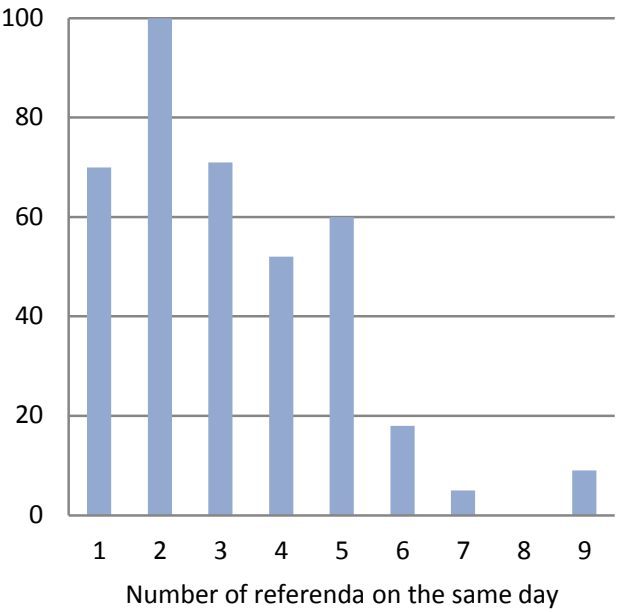

Notes: The figure shows on the x-axis the number of referenda on the same day and on the $y$-axis the total number of referenda (without counter proposals) for the respective category.

Except for the very first referendum on June 6,1848, all referenda have been held on a Sunday. Usually, Swiss voters go to the polls between one and four days a year ${ }^{7}$ to decide between a minimum of one and a maximum of nine distinct referenda issues. ${ }^{8}$ Voters may decide on cantonal and communal issues too, but they are clearly distinguishable to federal

7 Only in 1952, 1958, and 1985 were voters asked to go to the polls on 7, 5, and 5 days per year, respectively.

8 Although voters usually decide on five or fewer referenda the same day, since 1848, nine referenda decisions on the same day occurred on January 14, 1866, and May 18, 2003. Eight referenda decisions in one day has never been registered, and seven referenda decisions on one day only occurred on May 17 , 1992. 
referenda and do not systematically take place in all cantons/communities together with federal referenda. Panel (b) of Figure 1 shows the average number of referenda per day for all decades since 1848 . This number remained stable from 1870 to the 1960 s and then increased slightly.

Figure 2, panel (a), provides a histogram of the number of referenda per day excluding counterproposals, excluded because they are presented together with the original referendum, making the referendum a multiple decision between either the status quo, the proposed initiative, or the counterproposal.

During the current and past two centuries, there have been over 125 instances of days on which exactly one referendum was held; the remainder are days on which two or more referenda were voted on. By splitting these observations into subsamples before and after 1945 (see panels (b) and (c) of Figure 2), we show that the total number of referenda held the same day has changed over time. Before 1946, voters were more often asked to decide on a single referendum on one day, whereas from 1946 onward, the custom was rather two referenda on one day. In the empirical analysis, we account for such gradual long-term changes over the centuries by including decade fixed effects and exploring these time periods separately. All additional variables employed in the analysis, their sources, and a number of descriptive statistics are given in appendix Table A1.

\section{Identification of Parliamentary Influence}

We use our natural experimental setting across a 160-year time span to assess whether constituents' bounded rationality throws light on voting behavior; in particular, whether complexity increases voter reliance on simple rules of thumb, i.e. "follow the expert", in this case, "follow parliament". We anticipate that introducing the concept of satisficing goals may be linked to a stronger inclination to trust and rely on experts. For example, Morton and Tyran (2010) observe in a laboratory experimental setting that voters with low quality information seem to follow the rule of thumb of "letting the experts decide" (p. 41). In other words, they show that less informed voters delegate their votes to more informed voters even when it is not suboptimal to do so. This reliance on an expert once the task becomes more complex can be a normal practice that is enforced by habit and regularities of behavior (behavioral rules). Indeed, Heiner (1983) argues that behavioral rules arise because of some uncertainty as individuals distinguish between preferred and less preferred behavior. Such 
uncertainty leads to mechanisms that restrict flexibility in choosing potential actions, which results in selective attention to information.

To identify the effect of parliament's voting recommendation on constituents' real choices, therefore, we first distinguish between days when there is only one referendum and days when more than one referendum takes place. Although we note that parliament might always have some influence on how constituents decide, we anticipate that parliament's influence will be larger when the number of referenda per day is higher than one. As previously discussed, the open public discussion that takes place before every referendum is easier to follow when constituents need only decide on a single issue, meaning that their attention is not divided between two or more issues that must be settled. When faced with such decisions, Simon (1983) argues, "we all feel the overwhelming difficulty of being appropriately informed. But we do have ways of dealing with that difficulty, in matters of public policy as in matters of medicine or plumbing: we turn to experts. When we can't establish the relevant facts, we look for an expert who knows them and we listen to what he has to say. Sometimes we even take his advice without asking to have it fully explained" (pp. 94-95). The strength of our setting is that the constituents do not have to seek out experts or justify why these experts are credible, legitimate, or even likely to be right. Rather, we deal with the issue of alternative experts by including interest group voting recommendations since 1945 , before which such recommendations were not officially available or collected. ${ }^{9}$

It is to be expected that when more referenda are held on the same day, constituents are more likely to refer to outside help and recommendations in making their decisions. Hence, we identify the parliamentary influence on constituent choices using the number of referenda held on the same day and then measure the influence of these recommendations on boundedly rational constituents by focusing only on days on which two or more referenda take place. Thereby, we identify the differential impact of parliament's voting recommendation for dichotomous, inexpensive and frequently repeated decisions in more complex (more referenda a day) or less complex (a single referendum a day) environments. As mentioned we know the turnout for all referenda on the same day since 1884, so, because constituents incur the same costs for more referenda on the same day as for one, we can use differences in

${ }^{9}$ Simon (1983) raises the question of how we ensure that parliamentary members' own interests do not color the advice they give. In Switzerland, members of parliament are routinely required to disclose financial and economic ties or responsibilities that might lead to a conflict of interest. Simon, however, also refers to an element that is directly linked to human bounded rationality, namely if a person becomes involved in a particular activity, devoting a lot of time to that activity, she or he will assign it a greater value than without involvement. 
turnout within constituencies to identify which referendum on a given day attracted the most constituent attention and had the highest turnout. Likewise, if better informed constituents are more likely to cast a vote, relatively less informed constituents are not but may cast a vote based heavily on parliamentary recommendation. We can therefore identify the parliamentary influence by examining the outcomes of referenda with relatively lower turnout on days when more than one referendum was held. Such an assumption is valid because focus of attention is a major determinant of choice and a key mechanism of bounded rationality (Simon 1983). A key advantage of our setting, therefore, is that we can identify the voters' focus as they simultaneously express their preferences in the ballot box.

Finally, the structure of the natural experiment solves potential causality problems. Parliament issues its voting recommendation before constituents decide on precisely the same topic. The official pamphlet sent to voters clearly highlights parliament's recommendation and explains the topic of each referendum separately including the legislative changes to laws or the constitution. Whether one or more referenda are presented at once is not decided by the parliament itself but by the Federal Chancellery and depends on the number of legislative/constitutional issues that the parliament decided on. The highest voting turnout identifies the referendum which received the highest attention in the public discussion before the referendum took place. Thus, complexity is also exogenously determined by the number of referenda on the same day and the focus of attention defined by the referendum with the highest turnout. On voting day constituents go to the polls and decide which referendum to accept and which to reject knowing parliament's recommendation and knowing which referendum issue has their focus of attention. Our setting allows therefore to test the simple rule of thumb: "when complexity increases, follow parliament".

Table 1: Natural setting since 1848: Average probability of constituents accepting a referendum dependent on parliamentary recommendation and number of referenda the same day

\begin{tabular}{|c|c|c|c|}
\hline & Parliament suggests NO & Parliament suggests YES & First difference \\
\hline $\begin{array}{l}\text { Only one referendum a } \\
\text { day }\end{array}$ & $\begin{array}{c}17.750^{\star * *} \\
(1.191)\end{array}$ & $\begin{array}{c}60.439^{\star \star *} \\
(0.935)\end{array}$ & $\begin{array}{c}42.689^{* * *} \\
(1.514)\end{array}$ \\
\hline \multirow[t]{2}{*}{$\begin{array}{l}\text { More than one } \\
\text { referendum a day }\end{array}$} & $\begin{array}{c}12.295^{\star \star \star} \\
(0.584) \\
\end{array}$ & $\begin{array}{c}65.402^{\star \star \star} \\
(0.561) \\
\end{array}$ & $\begin{array}{c}53.108^{\star \star *} \\
(0.810) \\
\end{array}$ \\
\hline & $\begin{array}{c}-5.455^{\star \star \star} \\
(1.326)\end{array}$ & $\begin{array}{c}4.963^{* * *} \\
(1.090)\end{array}$ & $\begin{array}{c}10.419^{\star \star *} \\
(1.718)\end{array}$ \\
\hline
\end{tabular}

Notes: Values represent the average probability in percentages that constituents will accept a referendum, the first differences, and the difference in difference. Values in parentheses are standard error estimates. ***,**, and $*$ indicate a mean significance level of below $1 \%$, between 1 and $5 \%$, and between 5 and $10 \%$, respectively. 


\section{EMPIRICAL RESULTS OF A NATURAL EXPERIMENT}

\section{Baseline Results}

The main results from our analysis of 160 years of data are given in Table 1.

It is first worth noting that exploring such a long time period reduces the relevance of referenda type (topic) or the influence of particular parties. Rather, we analyze the probability of a constituency accepting a referendum dependent on whether parliament recommends a yes or no vote and whether there is only one or more than one referendum that day. If constituents are boundedly rational, they should react more to parliamentary recommendation when their attention is divided among several issues. This theoretical expectation corresponds exactly with our observations from the natural experiment. The probability of a constituency accepting a single referendum on a given day is $17.75 \%$ when parliament recommends a no vote but is 42.69 percentage points higher at $60.44 \%$ when parliament recommends a yes vote. ${ }^{10}$ However, the influence of parliament is even greater when there is more than one referendum per day: the probability of a constituency accepting a referendum falls to $12.30 \%$ when parliament recommends rejection but increases to $65.40 \%$ when parliament suggests acceptance. Thus, when there is more than one referendum on the same day, the difference in probability is approximately 53.11 and the difference in difference is approximately 10.42 percentage points. Put differently, when constituents must decide on more than one issue, the influence of parliamentary recommendation is 10.42 percentage points higher, which is consistent with the argument that people are boundedly rational and refer to recommendations when the number of issues increases. We also note that the influence of parliament increases symmetrically in more complex voting situations: If parliament suggests to vote no the probability that constituents really vote yes drops by 5.45 percentage points from $17.75 \%$ to $12.30 \%$ when more than one referendum per day is held while a recommendation to vote yes by parliament increases the probability that constituents vote yes by 4.96 percentage points from $60.44 \%$ in the case of a single referendum a day to 65.40 when more than one referendum per day is held. If constituents are boundedly rational we would precisely expect such a symmetric influence of the rule of thumb to follow parliament in more complex situations for yes and no recommendations.

\footnotetext{
${ }^{10}$ This change in the yes vote may indicate that parliament has already an influence on voters. However, it may also indicate that parliament suggests a yes vote for sensible issues where voters would have voted yes in any case. Our natural experiment only allows us to determine whether the influence of parliament increases when complexity increases too and constituents rely on simple rules of thumb.
} 
Table 2: Parliamentary influence on constituent referenda choices

\begin{tabular}{|c|c|c|c|c|c|c|c|c|c|}
\hline & \multicolumn{5}{|c|}{ Identification: More than one referendum } & \multicolumn{4}{|c|}{ Identification: Low turnout referendum } \\
\hline & (1) & (2) & (3) & (4) & (5) & (6) & (7) & (8) & (9) \\
\hline Years covered & $1848-2009$ & $1848-2009$ & $1848-2009$ & $1884-2009$ & $1884-2009$ & $1884-2009$ & $1884-2009$ & $1884-2009$ & $1884-2009$ \\
\hline Parliament suggests YES & $\begin{array}{l}1.9955^{* * *} \\
(0.1051)\end{array}$ & $\begin{array}{c}2.0107 * * * \\
(0.1052)\end{array}$ & $\begin{array}{c}2.1695 * * * \\
(0.1119)\end{array}$ & $\begin{array}{c}2.1190 * * * \\
(0.1067)\end{array}$ & $\begin{array}{c}2.1548 * * * \\
(0.1119)\end{array}$ & $\begin{array}{c}2.4834 * * * \\
(0.1212)\end{array}$ & $\begin{array}{c}2.5322 * * * \\
(0.1236)\end{array}$ & $\begin{array}{c}2.5480 * * * \\
(0.1261)\end{array}$ & $\begin{array}{c}2.5485 * * * \\
(0.1227)\end{array}$ \\
\hline $\begin{array}{l}\text { (Parliament suggests YES) * (More than } \\
\text { one referendum) }\end{array}$ & $\begin{array}{c}0.6559 * * * \\
(0.0857)\end{array}$ & $\begin{array}{c}0.6608 * * * \\
(0.0858)\end{array}$ & $\begin{array}{l}0.5883 * * * \\
(0.0950)\end{array}$ & $\begin{array}{c}0.6050 * * * \\
(0.0889)\end{array}$ & $\begin{array}{c}0.5699 * * * \\
(0.0958)\end{array}$ & & & & \\
\hline More than one referendum & $\begin{array}{l}-0.4445 * * * \\
(0.0735)\end{array}$ & $\begin{array}{c}-0.4446 * * * \\
(0.0735)\end{array}$ & $\begin{array}{c}-0.4734 * * * \\
(0.0810)\end{array}$ & $\begin{array}{l}-0.5583 * * * \\
(0.0765)\end{array}$ & $\begin{array}{c}-0.4868 * * * \\
(0.0818)\end{array}$ & & & & \\
\hline $\begin{array}{l}\text { (Parliament suggests YES) } * \text { (Low } \\
\text { turnout referendum) }\end{array}$ & & & & & & $\begin{array}{l}0.4010 * * * \\
(0.1113)\end{array}$ & $\begin{array}{c}0.3827 * * * \\
(0.1121)\end{array}$ & $\begin{array}{l}0.3234 * * * \\
(0.1098)\end{array}$ & $\begin{array}{c}0.2956 * * * \\
(0.1140)\end{array}$ \\
\hline Low turnout referendum & & & & & & $\begin{array}{l}-0.1201 \\
(0.1013)\end{array}$ & $\begin{array}{l}-0.1188 \\
(0.1013)\end{array}$ & $\begin{array}{l}-0.1013 \\
(0.1008)\end{array}$ & $\begin{array}{l}-0.0689 \\
(0.1014)\end{array}$ \\
\hline Number of referenda the same day & & & & & & $\begin{array}{c}0.0574 * * * \\
(0.0107)\end{array}$ & $\begin{array}{c}0.0559 * * * \\
(0.0107)\end{array}$ & $\begin{array}{l}0.0464 * * * \\
(0.0107)\end{array}$ & $\begin{array}{c}0.0748 * * * \\
(0.0143)\end{array}$ \\
\hline Counterproposal & & $\begin{array}{l}-0.2022 * * * \\
(0.0626)\end{array}$ & $\begin{array}{l}-0.2180 * * * \\
(0.0508)\end{array}$ & $\begin{array}{l}-0.3666 * * * \\
(0.0491)\end{array}$ & $\begin{array}{l}-0.3064 * * * \\
(0.0472)\end{array}$ & & $\begin{array}{l}-0.3487 * * * \\
(0.0511)\end{array}$ & $\begin{array}{l}-0.4157 * * * \\
(0.0488)\end{array}$ & $\begin{array}{c}-0.4030 * * * \\
(0.0514)\end{array}$ \\
\hline Turnout & & & & $\begin{array}{c}-2.2348 * * * \\
(0.1927)\end{array}$ & $\begin{array}{c}-1.9953 * * * \\
(0.1981)\end{array}$ & & & $\begin{array}{c}-1.6723 * * * \\
(0.2416)\end{array}$ & $\begin{array}{c}-1.4259 * * * \\
(0.2443)\end{array}$ \\
\hline Intercept & $\begin{array}{l}-1.6792 * * * \\
(0.0813)\end{array}$ & $\begin{array}{l}-1.6793 * * * \\
(0.0813)\end{array}$ & $\begin{array}{c}-1.5177 * * * \\
(0.3973)\end{array}$ & $\begin{array}{l}-0.4186 * * * \\
(0.1265)\end{array}$ & $\begin{array}{c}-0.7479 * * * \\
(0.2284)\end{array}$ & $\begin{array}{c}-2.3166 * * * \\
(0.1156)\end{array}$ & $\begin{array}{l}-2.3119 * * * \\
(0.1154)\end{array}$ & $\begin{array}{l}-1.4550 * * * \\
(0.1676)\end{array}$ & $\begin{array}{c}-2.6057 * * * \\
(0.3401)\end{array}$ \\
\hline Cantonal Fixed Effects & YES & YES & YES & YES & YES & YES & YES & YES & YES \\
\hline Decade Fixed Effects & NO & NO & YES & NO & YES & NO & NO & NO & YES \\
\hline DE Parliament suggests YES & 45.85 & 46.17 & 49.18 & 48.43 & 49.14 & 53.40 & 54.43 & 55.52 & 53.58 \\
\hline $\begin{array}{l}\text { DE (Parliament suggests YES) * (More } \\
\text { than one referendum) }\end{array}$ & 11.37 & 11.43 & 9.36 & 10.55 & 9.32 & & & & \\
\hline $\begin{array}{l}\text { DE (Parliament suggests YES) * (Low } \\
\text { turnout referendum) }\end{array}$ & & & & & & 7.18 & 6.73 & 5.56 & 5.57 \\
\hline Sample restriction & & & & & & $\begin{array}{c}>1 \\
\text { referendum }\end{array}$ & $\begin{array}{c}>1 \\
\text { referendum }\end{array}$ & $\begin{array}{c}>1 \\
\text { referendum }\end{array}$ & $\begin{array}{c}>1 \\
\text { referendum }\end{array}$ \\
\hline R2 & 0.2958 & 0.2964 & 0.325 & 0.3309 & 0.3445 & 0.3339 & 0.3502 & 0.3567 & 0.3671 \\
\hline Brier & 0.1929 & 0.1928 & 0.1862 & 0.1846 & 0.1817 & 0.1839 & 0.1808 & 0.1792 & 0.1765 \\
\hline No. Obs. & 14127 & 14127 & 14127 & 13502 & 13502 & 9961 & 9961 & 9961 & 9961 \\
\hline
\end{tabular}

Notes: The dependent variable for all logit estimations is "Constituency accepts referendum." Robust clustered standard error estimates for cantons (constituencies) are reported throughout the table. DE stands for discrete effect in the predicted probability. The effects for "Parliament suggests YES", "(Parliament suggests YES) * (Low turnout referendum)", "(Parliament suggests YES) * (More than one referendum)" represent discrete effects in percentage points for these coefficients when all other variables are evaluated at their median values. The evaluation of the interaction terms follows Ai and Norton (2003). ${ }^{* * *}, * *$, and * indicate a mean significance level o low $1 \%$, between 1 ind $5 \%$, and between 5 and $10 \%$, respectively. 
As shown in Table 2, a very similar picture emerges for a logit model analysis of the probability that a constituency will accept a referendum. Here, the dependent variable, used in all the remaining tables, is constituency acceptance of the referendum. For each of the specifications, we report robust standard errors clustered by constituency. ${ }^{11} \mathrm{We}$ also calculate discrete effects for the influence of parliamentary recommendation and the interaction terms, while holding all other variables fixed at their medians. ${ }^{12}$ It is also important to note that we count counterproposals and initiatives as one single referendum but include their acceptance/rejection in the data.

Specification (1) is a natural experimental setting similar to that reported in Table 1. The pseudo R2 is very high for a logit model (and indeed for this type of analysis) even though the model includes no other controls apart from cantonal dummies. As both interaction variables are exogenous to constituent referenda choices, the interaction term gives us the causal influence of parliament's recommendation in more complex voting situations. Thus, any variable not present in the estimations could only be characterized as omitted if it would influence the interaction term directly. We control for such potential influences in further estimates and refinements. As shown in Table 2, the interaction term is highly statistically significant at the $1 \%$ level with a positive sign. Thus, when there are more referenda per day, the parliamentary influence on constituent decisions is larger. Specifically, the discrete effects show that when there is only a single referendum proposed, constituents are 45.85 percentage points more likely to vote yes, while the interaction term indicates that this effect increases by 11.37 percentage points for more than one referendum.

Specification (2) includes a dummy for counterproposals to ensure that the observed effects are not a consequence of different reactions to parliament when there are more referenda and one is a counterproposal. Including the counterproposal variable, however, has barely any effect on our key variables (in fact, the quantitative effect is even a little larger). Specification (3) introduces decade dummies to represent technological and environmental changes that have reduced the transaction costs of information, potential changes in voter characteristics (e.g., average level of education), or simply a shift to more referenda over

\footnotetext{
${ }^{11}$ Observations are clustered by constituency in recognition of the likelihood that observations in the same constituency are not independent.

${ }^{12}$ For correct evaluation of the interaction term in logistic models, we follow Ai and Norton (2003): The discrete effect of the interaction term in our models is calculated as the change in the predicted probability from a situation where the parliament recommends yes and the second interaction variable is zero to a situation where parliament recommends yes and the other interaction variable is non-zero. Calculating the discrete effect of the interaction term directly as suggested by Puhani (2012) leads to similar (sometimes even quantitatively larger) results.
} 
time. Other changes that justify the use of such time dummies include granting women the right to vote at the federal level in 1971 and the emergence of the new canton of Jura in 1979 (first referendum February 18, 1979). The coefficient of the interaction term, however, remains statistically positively significant with a comparable discrete effect.

Specification (4) then restricts the sample to the 1884-2009 period to reflect the fact that voter turnout data are only available from 1884 (before which there was no systematic registration of either the electorate or the number of valid votes). Turnout not only measures voters' level of interest or how well informed they are, it also covers such aspects as environmental conditions (e.g., weather). Hence, it is valuable to control for voter turnout in case voters simply do not turn up when they are not well informed, particularly when there is more than one referendum. Our results indicate that turnout has no effect on the interaction term, and the discrete effect even increases slightly to over 10 percentage points, i.e. when more referenda are held the same day the influence of parliament's recommendation on constituents real choices is significantly higher. The base effect of turnout is also negative, which may indicate that voters come to the polls if they disagree (the status quo bias). This finding, however, should not affect our experimental setting, i.e. the higher effect of parliament's recommendation in more complex voting situations when constituents follow a rule of thumb. Specification (5) incorporates decade fixed effects to control for technological and environmental changes.

To reflect our second identification approach for the focus of attention, specifications (6) to (9) include an interaction term based on the "referenda that do not have the highest turnout on the same day" (low turnout referenda) rather than "more than one referendum." As always, because of data availability, the data sample begins in 1884 but by definition is restricted to cases with more than one referendum per day. In line with the previous results, the interaction term is positive, statistically significant and, at 7.18 percentage points, the discrete effect is surprisingly large given the small discrete effect expected if voters informed about only one referendum vote on no others. To ensure that the effects from the first identification strategy do not overlap with those based on referenda with low turnout, we also take into account "number of referenda the same day". In line with the earlier analysis, we include the counterproposals in specification (7), check for the effects of the turnout itself in specification (8) and (9) and in (9) we include decade fixed effects. Throughout all the estimations reported in Table 2, the interaction term is statistically significant at the $1 \%$ level with a discrete effect between 5.56 and 7.18 percentage points. All the remaining estimations always include cantonal and decade fixed effects. 


\section{Robustness}

Table 3 reports the results of our robustness tests. The first takes into account that the government's executive council (the federal council) also frequently makes a recommendation on a referendum, meaning that constituents may not only be influenced by parliament. For example, in three cases during our sample period, there was disagreement between the government and parliament. Even if we exclude these three cases, however, our results do not change (not reported here). More important, in many cases, the government remains neutral and expresses no preference (no position), so we examine voter responses to such a situation to gage whether constituents react to politician suggestions in general or only to the government or parliament.

Specification (1) uses a sample that begins in 1848 and includes an interaction term between government neutrality and our "more than one referendum" identifier. The results entirely confirm our expectation that constituents will not react more to a neutral position of the government if there is more than one referendum but will still react more to parliament's position if there is more than one referendum: The interaction term between "parliament suggests a yes vote" and "more than one referendum" remains highly statistically significant and positive, with a large discrete effect (14.32 percentage points) while the interaction term for "government neutral" and "more than one referendum" is both small and insignificant. Specification (2) employs a sample that starts in 1884 and includes turnout. The quantitative effects barely change for parliament's recommendation and the interaction term for "government neutral" and "more than one referendum" remains insignificant. Finally, specification (3) analyzes those referenda that do not have the highest turnout, restricting the sample (as before) to days with more than one referendum. Again, the interaction term for the government is not statistically significant, but the interaction term between for the parliamentary influence is highly significant and positive.

If politicians are in fact aware that their constituents are boundedly rational and more likely to follow parliamentary recommendations when there are more referenda on the same day, they may select to bundle referenda; particularly, if they are unsure whether the proposal will pass. If this really is the case, we should actually observe no differences because parliament's recommendations should be the same everywhere. Thus, if politicians actually do select the referendum day to increase the power of their recommendations, the effects measured so far would represent a lower bound estimate for the influence of parliament and the represent in any case evidence that constituents follow a rule of thumb. 
Table 3: Parliamentary influence on constituent referenda when government is neutral and members of parliament offer divergent suggestions

\begin{tabular}{|c|c|c|c|c|c|c|}
\hline & \multicolumn{3}{|c|}{ Government neutral position } & \multicolumn{3}{|c|}{$\begin{array}{c}25 \% \text { or more of members of parliament } \\
\text { have diverging suggestion }\end{array}$} \\
\hline & (1) & (2) & (3) & (4) & (5) & (6) \\
\hline Years covered & $1848-2009$ & $1884-2009$ & $1884-2009$ & $1848-2009$ & $1884-2009$ & $1884-2009$ \\
\hline Parliament suggests YES & $\begin{array}{l}1.8476 * * * \\
(0.1052)\end{array}$ & $\begin{array}{c}1.8610^{* * *} \\
(0.1106)\end{array}$ & $\begin{array}{c}2.4782^{* * *} \\
(0.1274)\end{array}$ & $\begin{array}{c}1.1985^{* * *} \\
(0.2866)\end{array}$ & $\begin{array}{c}1.1962 * * * \\
(0.3102)\end{array}$ & $\begin{array}{c}1.9922^{* * *} \\
(0.1685)\end{array}$ \\
\hline $\begin{array}{l}\text { (Parliament suggests YES) } * \\
\text { (More than one referendum) }\end{array}$ & $\begin{array}{c}0.8278 * * * \\
(0.0930)\end{array}$ & $\begin{array}{l}0.7789 * * * \\
(0.0968)\end{array}$ & & $\begin{array}{c}1.3938 * * * \\
(0.3106)\end{array}$ & $\begin{array}{c}1.3801 * * * \\
(0.3328)\end{array}$ & \\
\hline More than one referendum & $\begin{array}{l}-0.6865^{* * *} \\
(0.0850)\end{array}$ & $\begin{array}{l}-0.6836 * * * \\
(0.0855)\end{array}$ & & $\begin{array}{c}-0.7964 * * * \\
(0.2155)\end{array}$ & $\begin{array}{l}-0.7217 * * * \\
(0.2241)\end{array}$ & \\
\hline $\begin{array}{l}\text { (Parliament suggests YES) } * \\
\text { (Low turnout referendum) }\end{array}$ & & & $\begin{array}{l}0.2859 * * \\
(0.1215)\end{array}$ & & & $\begin{array}{c}0.9889 * * * \\
(0.1576)\end{array}$ \\
\hline Low turnout referendum & & & $\begin{array}{l}-0.0939 \\
(0.0996)\end{array}$ & & & $\begin{array}{c}-0.5107 * * * \\
(0.1249)\end{array}$ \\
\hline $\begin{array}{l}\text { (Government neutral) } * \text { (More } \\
\text { than one referendum) }\end{array}$ & $\begin{array}{c}0.0037 \\
(0.0698)\end{array}$ & $\begin{array}{c}0.0071 \\
(0.0724)\end{array}$ & & & & \\
\hline $\begin{array}{l}\text { (Government neutral) } *(\text { Low } \\
\text { turnout referendum })\end{array}$ & & & $\begin{array}{c}0.0067 \\
(0.0805)\end{array}$ & & & \\
\hline Government neutral & $\begin{array}{l}0.8814 * * * \\
(0.0671)\end{array}$ & $\begin{array}{c}0.8572 * * * \\
(0.0680)\end{array}$ & $\begin{array}{l}0.8751^{* * *} \\
(0.0624)\end{array}$ & & & \\
\hline $\begin{array}{l}\text { Number of referenda the same } \\
\text { day }\end{array}$ & & & $\begin{array}{c}0.0911 * * * \\
(0.0145)\end{array}$ & & & $\begin{array}{l}-0.0083 \\
(0.0187)\end{array}$ \\
\hline Counterproposal & $\begin{array}{l}-0.4327 * * * \\
(0.0506)\end{array}$ & $\begin{array}{c}-0.5017 * * * \\
(0.0496)\end{array}$ & $\begin{array}{l}-0.5541 * * * \\
(0.0540)\end{array}$ & $\begin{array}{l}-0.4181 * * * \\
(0.0652)\end{array}$ & $\begin{array}{c}-0.4439 * * * \\
(0.0641)\end{array}$ & $\begin{array}{c}-0.4557 * * * \\
(0.0682)\end{array}$ \\
\hline Turnout & & $\begin{array}{c}-1.7264 * * * \\
(0.1884)\end{array}$ & $\begin{array}{l}-1.1955 * * * \\
(0.2356)\end{array}$ & & $\begin{array}{l}-1.0280 * * \\
(0.4461)\end{array}$ & $\begin{array}{c}0.0283 \\
(0.4550)\end{array}$ \\
\hline Cantonal Fixed Effects & YES & YES & YES & YES & YES & YES \\
\hline Decade Fixed Effects & YES & YES & YES & YES & YES & YES \\
\hline DE Parliament suggests YES & 43.15 & 43.43 & 52.59 & 28.00 & 27.63 & 43.04 \\
\hline $\begin{array}{l}\text { DE (Parliament suggests YES) * } \\
\text { (More than one referendum) }\end{array}$ & 14.32 & 13.74 & & 26.59 & 26.78 & \\
\hline $\begin{array}{l}\text { DE (Parliament suggests YES) * } \\
\text { (Low turnout referendum) }\end{array}$ & & & 5.22 & & & 16.80 \\
\hline Sample restriction & & & $\begin{array}{c}>1 \\
\text { referendum }\end{array}$ & & & $\begin{array}{c}>1 \\
\text { referendum }\end{array}$ \\
\hline R2 & 0.3426 & 0.3602 & 0.3792 & 0.3254 & 0.3382 & 0.3657 \\
\hline Brier & 0.1825 & 0.1784 & 0.1741 & 0.1771 & 0.1745 & 0.1709 \\
\hline No. Obs. & 14127 & 13502 & 9961 & 4379 & 4229 & 3698 \\
\hline
\end{tabular}

Notes: The dependent variable for all logit estimations is "Constituency accepts referendum". Robust clustered standard error estimates for cantons (constituencies) are reported throughout the table. An intercept is always included. DE stands for discrete effect in the predicted probability. The effects for "Parliament suggests YES", "(Parliament suggests YES) * (Low turnout referendum)", "(Parliament suggests YES) * (More than one referendum)" represent discrete effects in percentage points for these coefficients when all other variables are evaluated at their median values. The evaluation of the interaction terms follows Ai and Norton (2003). ***, **, and *indicate a mean significance level of below $1 \%$, between 1 and $5 \%$; and between 5 and $10 \%$, respectively.

It may also be, however, that minorities in parliament might try to set the referendum day in their own favor; that is, in such a way that their position has more power than the parliamentary majority's. To take these potential strategic behaviors into account, we look at the majority by which parliament passed legislative proposals. The primary methodological problem is that systematic recording of the number of parliamentary members voting yes/no only began with the introduction of an electronic voting system in 1996, so for data before 
this, we had to refer to national council's collected stenographic protocols and records of which politicians voted for and against a proposal. Stenographic protocols, however, particularly up until 1870 and between 1930 and 1945, do not always mention the exact majorities, only the final parliamentary decision. Hence, we have no information on the exact majorities in a total of 113 cases.

To determine whether minority positions led the Federal Chancellery to strategically bundle referenda on the same day, specification (4) restricts the analysis only to recommendations on which $25 \%$ or more of members of parliament disagreed. Not only is the interaction term significant and positive but the discrete effect is higher than before. Thus, it is not the minorities who bundle/unbundle referenda on a single day; rather, they may only prevent the majority from strategically scheduling more referenda on the same day. This interpretation would explain why we now also find a higher effect of the influence of the parliamentary majority (i.e., parliamentary recommendation). Both specification (5), which uses data from 1884 onward, and specification (6), which analyzes referenda with low turnout (in line with specification (3)), also return a higher discrete effect.

We now explore different time periods and present the results in Table 4. In specifications (1) to (3), we exclude World War I and II, as those years represent exceptional circumstances. Such exclusion, however, has no effect on our key results. In specifications (4) to (5), we look at a more recent time period (1946 to 2009), a very stable era in Switzerland with good economic growth, increased wealth, and stable institutions. Although all interaction terms are significant, the discrete effect in specification (4) is relatively smaller, most probably because of the post-1945 tendency to hold more referenda on one day (see previous figures). Yet this finding also implies that the effect of the interaction with "low turnout referendum" should become more important, which is precisely the case-the discrete effect is 6.51 percentage points compared to around 5 percentage points in earlier estimates. Specifications (6) to (8) focus on the period up until 1945. Specification (6) produces the now typical result: the discrete effect is again higher because of a reference group with a sufficient number of observations (see Figure 2, panel b). In specification (7), however, for the first time, the interaction effect between "Parliament suggests YES" and "Low turnout referendum" is not statistically significant. We assume two possible reasons for this result: (1) the sample is comparatively small or (2) the instances of two or more referenda before 1945 are few, so low turnout referenda are identified mostly on days with two referenda. We solve this bias in specification (8) by controlling for days with only one referendum. 
Table 4: Robustness tests with different periods - Influence of Parliament on constituents' choices in referenda

\begin{tabular}{|c|c|c|c|c|c|c|c|c|}
\hline & \multicolumn{3}{|c|}{ Without World War I and World War II } & \multicolumn{2}{|c|}{ From 1946 to 2009} & \multicolumn{3}{|c|}{ From 1884 to 1945} \\
\hline & (1) & (2) & (3) & (4) & (5) & (6) & (7) & (8) \\
\hline Years covered & $1848-2009$ & $1884-2009$ & $1884-2009$ & $1945-2009$ & $1945-2009$ & 1884-1945 & $1884-1945$ & $1884-1945$ \\
\hline Parliament suggests YES & $\begin{array}{c}2.2389 * * * \\
(0.1235)\end{array}$ & $\begin{array}{c}2.2305^{* * *} \\
(0.1239)\end{array}$ & $\begin{array}{c}2.5415^{* * *} \\
(0.1230)\end{array}$ & $\begin{array}{c}2.5505^{* * *} \\
(0.1555)\end{array}$ & $\begin{array}{c}2.5790 * * * \\
(0.1287)\end{array}$ & $\begin{array}{c}1.5306^{* * *} \\
(0.1833)\end{array}$ & $\begin{array}{c}2.0152^{* * *} \\
(0.2363)\end{array}$ & $\begin{array}{c}1.6656^{* * *} \\
(0.1702)\end{array}$ \\
\hline $\begin{array}{l}\text { (Parliament suggests YES) * (More than one } \\
\text { referendum) }\end{array}$ & $\begin{array}{c}0.5246 * * * \\
(0.0933)\end{array}$ & $\begin{array}{c}0.4945 * * * \\
(0.0934)\end{array}$ & & $\begin{array}{l}0.2557 * * \\
(0.1202)\end{array}$ & & $\begin{array}{c}0.7568 * * * \\
(0.1812)\end{array}$ & & \\
\hline More than one referendum & $\begin{array}{c}-0.4215^{* * *} \\
(0.0834)\end{array}$ & $\begin{array}{c}-0.4271 * * * \\
(0.0842)\end{array}$ & & $\begin{array}{l}-0.1953 \\
(0.1211)\end{array}$ & & $\begin{array}{c}-0.7927 * * * \\
(0.1490)\end{array}$ & & \\
\hline $\begin{array}{l}\text { (Parliament suggests YES) * (Low turnout } \\
\text { referendum) }\end{array}$ & & & $\begin{array}{l}0.2889 * * \\
(0.1137)\end{array}$ & & $\begin{array}{c}0.3156 * * * \\
(0.1162)\end{array}$ & & $\begin{array}{c}0.1186 \\
(0.2419)\end{array}$ & $\begin{array}{c}0.6062 * * * \\
(0.1695)\end{array}$ \\
\hline Low turnout referendum & & & $\begin{array}{l}-0.0468 \\
(0.1011)\end{array}$ & & $\begin{array}{l}-0.0129 \\
(0.1019)\end{array}$ & & $\begin{array}{l}-0.3216 \\
(0.2323)\end{array}$ & $\begin{array}{c}-0.7438 * * * \\
(0.1652)\end{array}$ \\
\hline Number of referenda the same day & & & $\begin{array}{c}0.0734 * * * \\
(0.0143)\end{array}$ & & $\begin{array}{c}0.0853 * * * \\
(0.0150)\end{array}$ & & $\begin{array}{c}-1.1675 * * * \\
(0.1133)\end{array}$ & $\begin{array}{c}-0.9466 * * * \\
(0.1283)\end{array}$ \\
\hline Exactly one referendum per day & & & & & & & & $\begin{array}{c}-1.3179 * * * \\
(0.1752)\end{array}$ \\
\hline Counterproposal & $\begin{array}{c}-0.3439 * * * \\
(0.0514)\end{array}$ & $\begin{array}{c}-0.4262 * * * \\
(0.0478)\end{array}$ & $\begin{array}{l}-0.4604 * * * \\
(0.0535)\end{array}$ & $\begin{array}{c}-0.5698 * * * \\
(0.0549)\end{array}$ & $\begin{array}{c}-0.5050 * * * \\
(0.0589)\end{array}$ & $\begin{array}{l}0.9836 * * * \\
(0.1427)\end{array}$ & $\begin{array}{c}0.7162 * * * \\
(0.1896)\end{array}$ & $\begin{array}{c}1.0211^{* * *} \\
(0.1519)\end{array}$ \\
\hline Turnout & & $\begin{array}{c}-1.9745^{* * *} \\
(0.2006)\end{array}$ & $\begin{array}{c}-1.4116^{* * *} \\
(0.2448)\end{array}$ & $\begin{array}{c}-1.9797 * * * \\
(0.3172)\end{array}$ & $\begin{array}{c}-1.7267 * * * \\
(0.3806)\end{array}$ & $\begin{array}{c}-2.1293^{* * *} \\
(0.3014)\end{array}$ & $\begin{array}{c}-1.0739 * * \\
(0.5206)\end{array}$ & $\begin{array}{c}-2.0597 * * * \\
(0.3105)\end{array}$ \\
\hline Cantonal Fixed Effects & YES & YES & YES & YES & YES & YES & YES & YES \\
\hline Decade Fixed Effects & YES & YES & YES & YES & YES & YES & YES & YES \\
\hline DE Parliament suggests YES & 50.42 & 50.52 & 53.40 & 55.62 & 53.48 & 36.50 & 44.48 & 39.37 \\
\hline $\begin{array}{l}\text { DE (Parliament suggests YES) * (More than } \\
\text { one referendum) }\end{array}$ & 8.24 & 7.96 & & 3.82 & & 13.57 & & \\
\hline $\begin{array}{l}\text { DE (Parliament suggests YES) * (Low } \\
\text { turnout referendum) }\end{array}$ & & & 5.63 & & 6.51 & & 3.89 & 9.80 \\
\hline Sample restriction & & & $>1$ referendum & & $>1$ referendum & & $>1$ referendum & \\
\hline R2 & 0.323 & 0.3424 & 0.362 & 0.374 & 0.3801 & 0.2854 & 0.3653 & 0.3079 \\
\hline Brier & 0.1866 & 0.1822 & 0.1776 & 0.1753 & 0.1734 & 0.1922 & 0.1781 & 0.1882 \\
\hline No. Obs. & 13652 & 13027 & 9861 & 10577 & 8686 & 2925 & 1275 & 2925 \\
\hline
\end{tabular}

Notes: The dependent variable for all logit estimations is "Constituency accepts referendum". Robust clustered standard error estimates for cantons (constituencies) are reported throughout the table. An intercept is always included. DE stands for discrete effect in the predicted probability. The effects for "Parliament suggests YES", "(Parliament suggests YES) * (Low turnout referendum)", "(Parliament suggests YES) * (More than one referendum)" represent discrete effects in percentage points for these coefficients when all other variables are evaluated at their median values. The evaluation of the interaction terms follows Ai and Norton (2003).
$* * *, * *$, and * indicate a mean significance level of below $1 \%$, between 1 and $5 \%$, and between 5 and $10 \%$, respectively. 


\begin{tabular}{lc}
\hline Years covered & $1848-2009$ \\
\hline Parliament suggests YES & $2.2565 * * *$ \\
& $(0.0924)$ \\
(Parliament suggests YES) $*$ (More & $0.7417 * * *$ \\
than two referenda) & $(0.0765)$ \\
More than two referenda & $-0.6557 * * *$ \\
& $(0.0713)$
\end{tabular}

(Parliament suggests YES) * (More than three referenda)

$$
\begin{gathered}
0.8862 * * * \\
(0.1130) \\
-0.3541 * * * \\
(0.0875)
\end{gathered}
$$

More than three referenda

(Parliament suggests YES) * (Number

of referenda the same day)

Number of referenda the same day

$$
0.1740 * * *
$$

(Parliament suggests YES) * (Low turnout referendum)

$0.5391 * * *$

(0.1538)

$-0.1951$

$(0.1260)$

\section{$0.0786 * *$}

(0.0319)

Exactly two or three referenda the same day

Counterproposal

$$
\begin{gathered}
-0.2149 * * * \\
(0.0506)
\end{gathered}
$$

$-0.7686 * * *$

(0.0785)

$-3.1623 * * *$

(0.5265)

Turnout

Cantonal Fixed Effects

Decade Fixed Effects

DE Parliament suggests YES

DE (Parliament suggests YES) * (More

than two referenda)

DE (Parliament suggests YES) * (More

than three referenda)

DE (Parliament suggests YES) *

(Number of referenda the same day)

DE (Parliament suggests YES) * (Low

turnout referendum)

Sample restriction

R2

Brier

No. Obs.

14127

0.186

14127

YES
YES
50.84

10.74

YES

YES

53.47

YES

YES

52.08

$0.0850 * *$

(0.0366)

$-0.1793 * * *$

$0.8113 * * *$

(0.1964)

$-0.2158$

(0.1582)

$-0.0437$

(0.0326)

$-0.1918 * * *$
$(0.0511)$

$-0.4511 * * *$

$-0.2083 * * *$

(0.1032)

(0.0512)

$-3.9928 * * *$

(0.8108)

YES

YES

YES

YES

Notes: The dependent variable for all logit estimations is "Constituency accepts referendum". Robust clustered standard error estimates for cantons (constituencies) are reported throughout the table. An intercept is always included. DE stands for discrete effect in the predicted probability. The effects for "Parliament suggests YES", "(Parliament suggests YES) * (Low turnout referendum)", "(Parliament suggests YES) * (More than one referendum)" represent discrete effects in percentage points for these coefficients when all other variables are evaluated at their median values. The evaluation of the interaction terms follows Ai and Norton (2003). $* *, * *$, and * indicate a mean significance level of below $1 \%$, between 1 and $5 \%$, and between 5 and $10 \%$, respectively. 


\section{Refinements}

We now refine our specifications as follows: In specification (1) of Table 5, we analyze the interaction term that represents more than two referenda instead of more than one and also control for the variable "exactly two referenda on the same day." Again, the interaction is positively significant, with a discrete effect over 10 percentage points. These results demonstrate that most of the previous effects hold especially when there are more referenda per day. We apply the same approach to specification (2) using our second identification strategy ("low turnout referendum"), although it should again be stressed that the dataset used in this estimation is restricted to days with more than two referenda. In specifications (3) and (4), we go a step further by concentrating on three or more referenda. In all cases, the interaction term is significantly positive and the discrete effects are larger than in specifications (1) and (2). Finally, specification (5) runs the interaction directly with the number of referenda per day (instead of with a dummy) and we thus suppose a change from one to two referenda for the discrete effect. The interaction term, however, is again significantly positive.

Because interest groups may also give voting recommendations, our next step is to investigate their effect (see Table 6) using official interest group voting recommendations from 1945, when they were first available or officially collected. We have data for three groups whose interest is the economy, Zentralverband schweizerischer ArbeitgeberOrganisationen, Economiesuisse, and Schweizerischer Gewerbeverband; three that cover unions, Schweizerischer Gewerkschaftsbund, and Travail.Suisse, which merged with Vereinigung schweizerischer Angestelltenverbände in 2002; and one that concentrates on farmers, Schweizerischer Bauernverband. Although other interest groups and regional organizations exist, these seven are arguably the most important and have the highest number of active participants. We evaluate only those referenda for which at least one interest group made an official voting recommendation and construct dummies that identify whether the interest group recommendations are divergent or whether all interest groups suggested a yes vote. As Table 6 shows, in specification (1), the interaction term is not significant when interest groups have divergent opinions and, as expected, only the interaction term for parliamentary recommendation remains significant. 
Table 6: Parliamentary influence on constituent referenda choices in the presence of interest group recommendations

$\begin{array}{cc}\text { At least one interest group's suggestion } & \begin{array}{c}\text { More than two interest } \\ \text { groups' suggestions }\end{array}\end{array}$

(1) (2) (3) (4) (5) (6) (5)

\begin{tabular}{|c|c|c|c|c|c|c|}
\hline Years covered & $1945-2009$ & $1945-2009$ & $1945-2009$ & $1945-2009$ & $1945-2009$ & $1945-2009$ \\
\hline $\begin{array}{l}\text { Parliament suggests YES } \\
\text { Y }\end{array}$ & $\begin{array}{l}2.4929 * * * \\
(0.1550)\end{array}$ & $\begin{array}{c}2.6452^{* * *} \\
(0.1348)\end{array}$ & $\begin{array}{l}1.4803^{* * *} \\
(0.2107)\end{array}$ & $\begin{array}{c}1.8857^{* * *} \\
(0.1760)\end{array}$ & $\begin{array}{l}1.5476^{* * *} \\
(0.2280)\end{array}$ & $\begin{array}{l}1.9089 * * * \\
(0.1895)\end{array}$ \\
\hline $\begin{array}{l}\text { (Parliament suggests YES) * } \\
\text { (More than one referendum) }\end{array}$ & $\begin{array}{c}0.3899 * * * \\
(0.1225)\end{array}$ & & $\begin{array}{c}0.7320 * * * \\
(0.1709)\end{array}$ & & $\begin{array}{l}0.7842 * * * \\
(0.1792)\end{array}$ & \\
\hline More than one referendum & $\begin{array}{l}-0.2176 * \\
(0.1278)\end{array}$ & & $\begin{array}{l}-0.3822 \\
(0.2405)\end{array}$ & & $\begin{array}{l}-0.6489 * * * \\
(0.2410)\end{array}$ & \\
\hline $\begin{array}{l}\text { (Parliament suggests YES) } * \text { (Low } \\
\text { turnout referendum) }\end{array}$ & & $\begin{array}{l}0.3130 * * \\
(0.1282)\end{array}$ & & $\begin{array}{c}0.4612 * * * \\
(0.1533)\end{array}$ & & $\begin{array}{c}0.6384 * * * \\
(0.1724)\end{array}$ \\
\hline Low turnout referendum & & $\begin{array}{l}-0.0268 \\
(0.1137)\end{array}$ & & $\begin{array}{l}-0.0983 \\
(0.1482)\end{array}$ & & $\begin{array}{l}-0.6094 * * * \\
(0.1979)\end{array}$ \\
\hline $\begin{array}{l}\text { (Interest groups divergent) } * \\
\text { (More than one referendum) }\end{array}$ & $\begin{array}{c}0.0901 \\
(0.0858)\end{array}$ & & $\begin{array}{c}0.0565 \\
(0.2557)\end{array}$ & & $\begin{array}{c}0.3053 \\
(0.2869)\end{array}$ & \\
\hline $\begin{array}{l}\text { (Interest groups divergent) } * \\
\text { (Low turnout referendum) }\end{array}$ & & $\begin{array}{l}-0.0799 \\
(0.0926)\end{array}$ & & $\begin{array}{l}-0.0610 \\
(0.1823)\end{array}$ & & $\begin{array}{c}0.3241 \\
(0.2202)\end{array}$ \\
\hline Interest groups divergent & $\begin{array}{l}-0.5250 * * * \\
(0.0879)\end{array}$ & $\begin{array}{l}-0.3658 * * * \\
(0.0861)\end{array}$ & $\begin{array}{c}0.9703 * * * \\
(0.1873)\end{array}$ & $\begin{array}{l}1.0921 * * * \\
(0.2225)\end{array}$ & $\begin{array}{l}0.9398^{* * *} \\
(0.2402)\end{array}$ & $\begin{array}{c}1.1358^{* * *} \\
(0.2352)\end{array}$ \\
\hline $\begin{array}{l}\text { (All interest groups suggest YES) } \\
* \text { (More than one referendum) }\end{array}$ & & & $\begin{array}{l}-0.1689 \\
(0.2553)\end{array}$ & & $\begin{array}{l}-0.3396 \\
(0.3189)\end{array}$ & \\
\hline $\begin{array}{l}\text { (All interest groups suggest YES) } \\
* \text { (Low turnout referendum) }\end{array}$ & & & & $\begin{array}{l}-0.0834 \\
(0.2169)\end{array}$ & & $\begin{array}{c}0.2910 \\
(0.2546)\end{array}$ \\
\hline All interest groups suggest YES & & & $\begin{array}{c}1.9742 * * * \\
(0.2076)\end{array}$ & $\begin{array}{c}1.8739 * * * \\
(0.2554)\end{array}$ & $\begin{array}{l}2.1422 * * * \\
(0.2993)\end{array}$ & $\begin{array}{c}1.7046 * * * \\
(0.2653)\end{array}$ \\
\hline $\begin{array}{l}\text { Number of referenda the same } \\
\text { day }\end{array}$ & & $\begin{array}{c}0.0887 * * * \\
(0.0146)\end{array}$ & & $\begin{array}{l}0.0811 * * * \\
(0.0149)\end{array}$ & & $\begin{array}{l}0.1212 * * * \\
(0.0197)\end{array}$ \\
\hline Counterproposal & $\begin{array}{l}-0.5686 * * * \\
(0.0643)\end{array}$ & $\begin{array}{c}-0.4293 * * * \\
(0.0781)\end{array}$ & $\begin{array}{c}-0.5374 * * * \\
(0.0674)\end{array}$ & $\begin{array}{l}-0.4096 * * * \\
(0.0831)\end{array}$ & $\begin{array}{c}-0.6590 * * * \\
(0.0740)\end{array}$ & $\begin{array}{l}-0.4460 * * * \\
(0.0880)\end{array}$ \\
\hline Turnout & $\begin{array}{l}-2.2539 * * * \\
(0.3417)\end{array}$ & $\begin{array}{l}-2.1951^{* * *} \\
(0.4138)\end{array}$ & $\begin{array}{c}-2.0763 * * * \\
(0.3595)\end{array}$ & $\begin{array}{l}-2.0928 * * * \\
(0.4258)\end{array}$ & $\begin{array}{c}-2.0752 * * * \\
(0.3933)\end{array}$ & $\begin{array}{l}-2.2142 * * * \\
(0.4712)\end{array}$ \\
\hline Cantonal Fixed Effects & YES & YES & YES & YES & YES & YES \\
\hline Decade Fixed Effects & YES & YES & YES & YES & YES & YES \\
\hline DE Parliament suggests YES & 55.23 & 56.58 & 22.32 & 25.52 & 24.07 & 23.99 \\
\hline $\begin{array}{l}\text { DE (Parliament suggests YES) * } \\
\text { (More than one referendum) }\end{array}$ & 6.35 & & 11.25 & & 7.54 & \\
\hline $\begin{array}{l}\text { DE (Parliament suggests YES) * } \\
\text { (Low turnout referendum) }\end{array}$ & & 5.73 & & 8.98 & & 3.24 \\
\hline Sample restriction & $\begin{array}{l}>= \\
\text { group }\end{array}$ & $\begin{array}{l}>=1 \text { interest } \\
\text { group } \&>1 \\
\text { referendum }\end{array}$ & $\begin{array}{c}>= \\
\text { group }\end{array}$ & $\begin{array}{l}>=1 \text { interest } \\
\text { group } \&>1 \\
\text { referendum }\end{array}$ & $\begin{array}{c}>=2 \text { interest } \\
\text { groups }\end{array}$ & $\begin{array}{c}>=2 \text { interest } \\
\text { groups } \&>1 \\
\text { referendum }\end{array}$ \\
\hline R2 & 0.4005 & 0.4087 & 0.4219 & 0.429 & 0.4158 & 0.4259 \\
\hline Brier & 0.1688 & 0.1666 & 0.1648 & 0.1626 & 0.1673 & 0.1643 \\
\hline No. Obs. & 10201 & 8385 & 10201 & 8385 & 8932 & 7516 \\
\hline
\end{tabular}

Notes: The dependent variable for all logit estimations is "Constituency accepts referendum". Robust clustered standard error estimates for cantons (constituencies) are reported throughout the table. An intercept is always included. DE stands for discrete effect in the predicted

probability. The effects for "Parliament suggests YES", "(Parliament suggests YES) * (Low turnout referendum)", "(Parliament suggests YES) *

(More than one referendum)" represent discrete effects in percentage points for these coefficients when all other variables are evaluated at their median values. The evaluation of the interaction terms follows Ai and Norton (2003). ***, **, and $*$ indicate a mean significance level of below 1

$\%$, between 1 and $5 \%$, and between 5 and $10 \%$, respectively. 
Specification (2) focuses only on the "Low turnout referendum". The coefficient of the interaction term for these referenda and interest groups is insignificant while the interaction term for the recommendation of the parliament and referenda that do not have the highest turnout is statistically significant. Thus, the results are consistent even when controlling for interest groups.

Specifications (3) and (4) test whether citizens react more to interest groups when there is more than one referendum and interest groups clearly suggest a yes vote. The insignificance of the interaction with interest groups and number of referenda indicates that when constituents are boundedly rational, they listen to parliament not interest groups, possibly because elected politicians are their representatives in the political arena. Nonetheless, recognizing that the results of the previous specifications could have been affected if only one interest group made an official recommendation, in specifications (5) and (6), we attempt to avoid such problems by restricting the sample to those referenda in which at least two interest groups expressed an opinion. The previously obtained results remain robust: Constituents follow the rule of thumb of "following parliament's recommendation" when more referenda are held the same day and in referenda that did not obtain their focus of attention.

\section{CONCLUSIONS}

This study explores whether a higher level of complexity leads to an increased reliance on expert knowledge, a topic on which, surprisingly, there seems to be little empirical evidence. Specifically, we exploit a natural experimental setting of voter practices in Switzerland, whose institutional environment has been stable since 1848. The dataset for this unique setting includes information on voting behavior in referenda over a 160-year period (1848-2009) that spans three centuries. Our results suggest that humans follow simple rules of thumb by relying on the expert specialist when several simultaneous problems demand concentrated attention.

We model complexity in two distinct ways: by distinguishing between days with only one referendum and days with two or more referenda and by focusing only on the latter. First, in line with our prediction that when more referenda are held on the same day, constituents will be more likely to seek outside help, we use the number of referenda held on the same day to identify the influence of parliament on constituent choices. We find evidence that parliamentary influence is greater when the number of referenda is higher than when there is 
only one referendum per day. Second, recognizing that on days with two or more referenda, constituents incur the same costs for turning up for the first as for the second or third referendum on the same day, we use the differences in turnout within constituencies to identify which referendum of a given day attracted the most attention. Most particularly, by focusing on referenda with a relatively lower turnout on multiple referenda days, we identify the influence of parliamentary recommendations when constituents are boundedly rational and follow simple rules of thumb.

The strength of this empirical design is that we can use the percentage of voter turnout to directly identify voters' focus of attention when the choices are multiple. Not only is the quantitative effect large, but it remains consistently so throughout our numerous robustness tests and refinements, such as excluding World War I and II, exploring different time periods, controlling for potential strategic behavior, and making government opinion neutral. We also control for the effects of interest groups and show that constituents are more likely to listen to parliament for their recommendations than to interest groups.

Overall, our results show that a bounded rationality framework can throw light on how people vote and, once the (voting) task is held constant over a long period of time, provide empirical evidence on procedural rationality. Yet most of the voting literature so far focuses keenly on why people vote in an attempt to understand the paradox of not voting (see, e.g., Feddersen 2004 for an overview). The simplicity of our setting also allows us to identify the effect of parliamentary voting recommendations on constituents' real choices while clearly revealing the preferences of both the constituents and parliament. Most particularly, we identify a strong invariance in voting behavior that almost resembles a law of qualitative structure (Newell and Simon 1976). ${ }^{13}$ We further observe a tendency for voters to follow the rule of thumb or heuristic that when many problems demand concentrated attention simultaneously, humans are more likely to rely on expert advice. That this behavior remains robust over three centuries despite environmental changes implies a simple choice mechanism that explains a substantial number of observed choices. Our results therefore provide valuable insights into how humans use limited computational capacity to deal with differences in information complexity, which always arise in modern societies and when dealing with political matters We conclude with a quote from Simon (1978) who above all stresses the importance of seeing attention as a scarce resource: "[When] important new policies must be

13 Simon (1990) makes a statement about psychology that can also be applied to other social sciences: "Psychology does not much resemble classical mechanics, nor should it aim to do so. Its laws are, and will be, limited in range and generality and will be mainly qualitative" (p. 2). 
formulated, public and official attention must be focused on one or a few matters. Other concerns, no matter how pressing, must wait their turn on the agenda... The management of attention and tracing indirect consequences of action are two of the basic issues of procedural rationality that confront a modern society... "Reasonable men" reach "reasonable" conclusions in circumstances where they have no prospect of applying classical models of substantive rationality. We know only imperfectly how they do it... the study of procedural rationality in circumstances where attention is scarce, where problems are immensely complex, and where crucial information is absent presents a host of challenging and fundamental research problems to anyone who is interested in the rational allocation of scarce resources" (pp. 13-14). 


\section{REFERENCES}

Ai, C., Norton, E. C. (2003), Interaction Terms in Logit and Probit models, Economics Letters 80(1), 123-129

Baumol, W. J. (2004). On Rational Satisficing, in: M. Augier and J. G. March (eds.), Models of a Man. Essays in Memory of Herbert A. Simon. Cambridge, Massachusetts: MIT Press, pp. 57-66.

Baumol, W. J. and R. E. Quandt (1964). Rule of Thumb and Optimally Imperfect Decisions, American Economic Review. 54: 23-46.

Clark, J. M. (1918). Economics and Modern Psychology: I, Journal of Political Economy. 26: 1-30.

Conlisk, J. (1996). Why Bounded Rationality?, Journal of Economic Literature. 34: 669-700.

Crain, W. M., D. R. Leavens, and L. Abbot (1987). Voting and Not Voting at the Same Time, Public Choice. 53: 221-229.

Downs, A. (1957). An Economic Theory of Democracy. New York: Harper \& Row.

Eichenberger, R. D. Stadelmann and M. Portmann (2012). A Comparative Analysis of the Voting Behavior of Constituents and their Representatives for Public Debts, Constitutional Political Economy. 23: 244-260

Feddersen, T. J. (2004). Rational Choice Theory and the Paradox of Not Voting, Journal of Economic Perspectives. 18: 99-112.

Frey, B. S. (1994). Direct Democracy: Politico-Economic Lessons from Swiss Experience, American Economic Review. 84: 338-42.

Friedman, M. (1953). Essays in Positive Economics. Chicago: University of Chicago Press.

Gigerenzer, G., R. Hertwig, and T. Pachur (2011). Heuristics. The Foundation of Adaptive Behavior. Oxford: Oxford University Press.

Greenberg, D. S. The Scope of the Initiative and Referendum in California, California Law Review. 54: 1717-1748.

Grönlund, K. and M. Setälä (2007). Political Trust, Satisfaction and Voter Turnout, Comparative European Politics. 5: 400-422.

Heiner, R. A. (1983). The Origin of Predictable Behavior. American Economic Review. 73: $560-595$. 
Hodgson, G. M. (1997). The Ubiquity of Habits and Rules, Cambridge Journal of Economics. 21: 663-684.

Kahneman, D. (2003). Maps of Bounded Rationality: Psychology for Behavioral Economics. American Economic Review. 93: 1449-1475.

Morton, R. and J.-R. Tyran (2010). Let the Experts Decide? Asymmetric Information, Abstention, and Coordinaton in Standing Committees, unpublished manuscript.

Newell, A. and H. A. Simon (1976). Computer Science as Empirical Inquiry: Symbols and Search, Communication of the ACM. 19: 113-125.

Portmann, M., D. Stadelmann and R. Eichenberger (2012). District Magnitude and Representation of the Majority's Preferences: Quasi-Experimental Evidence from Popular and Parliamentary Votes, Public Choice. 151: 585-610.

Puhani, P. A. (2012). The treatment effect, the cross difference, and the interaction term in nonlinear 'difference-in-differences' models, Economics Letters 115: 85-87.

Reutskaja, E., R. Nagel, C. F. Camerer, and A. Rangel (2001). Search Dynamics in Consumer Choice under Time Pressure: An Eye-Tracking Study, American Economic Review. 101: 900-926.

Schneider, F., W. W. Pommerehne, B. S. and Frey. (1981). Politico-Economic Interdependence in a Direct Democracy: The case of Switzerland, in D. A. Hibbs and H. Fassbender (ed.), Contemporary Political Economy, Studies on the Interdependence of Politics and Economics, Amsterdam: North Holland.

Shachar, R. and B. Nalebuff (1999). Follow the Leader: Theory and Evidence on Political Participation, American Economic Review. 89: 525-547.

Simon, H. A. (1955). A Behavioral Model of Rational Choice, Quarterly Journal of Economics. 69: 99-118.

Simon, H. A. (1956). Rational Choice and the Structure of the Environment, Psychological Review. 63: 129-138.

Simon, H. A. (1957). Models of Man. New York: John Wiley \& Sons.

Simon, H. A. (1959). Theories of Decision-Making in Economics and Behavioral Science, American Economic Review. 49: 253-283.

Simon, H. A. (1972). Theories of Bounded Rationality, in C.B. McGuire and R. Radner (eds.), Decision and Organization. North-Holland Publishing Company.

Simon, H. A. (1978). Rationality as Process and as Product of Thought, American Economic Review. 68: 1-16.

Simon, H. A. (1983). Reason in Human Affairs. Stanford: Stanford University Press. 
Simon, H.A. (1986). Rationality in Psychology and Economics, Journal of Business. 59: S209-S224.

Simon, H. A. (1990). Invariants of Human Behavior, Annual Review of Psychology, 41: $1-19$.

Simon, H. A. (1992). Methodological Foundations of Economics, in: J.L. Auspitz, W. W. Gasparski, M. K. Mlicki, and K. Szaniawski (eds.), Praxiologies and the Philosophy of Economics. New Brunswick, NJ: Transactions Publishers.

Simon, H. A. (1996). The Science of the Artificial. Cambridge, Massachusetts: MIT Press.

Simon, H. A. (2000). Bounded Rationality in Social Science: Today and Tomorrow. Mind \& Society. 1: 2-39.

Stadelmann, D., M. Portmann, R. Eichenberger (2012). Quantifying Parliamentary Representation of Constituents' Preferences with Quasi-Experimental Data, Journal of Comparative Economics. forthcoming. 


\begin{tabular}{|c|c|c|c|c|c|c|c|c|}
\hline \multirow{2}{*}{ Variable } & \multirow{2}{*}{ Description \& Source } & \multirow[b]{2}{*}{$\begin{array}{l}\text { Available } \\
\text { since }\end{array}$} & \multicolumn{2}{|c|}{$1848-2009$} & \multicolumn{2}{|c|}{$1848-1945$} & \multicolumn{2}{|c|}{$1946-2009$} \\
\hline & & & Mean & $S D$ & Mean & $S D$ & Mean & $S D$ \\
\hline $\begin{array}{l}\text { Constituency accepts } \\
\text { referendum }\end{array}$ & $\begin{array}{l}\text { Indicator variable: Constituency (canton) accepts the referendum. Federal Statistical } \\
\text { Office and Swissvotes Database. }\end{array}$ & 1848 & 0.4907 & 0.4999 & 0.4856 & 0.4999 & 0.4924 & 0.5000 \\
\hline Parliament suggests YES & $\begin{array}{l}\text { Indicator variable: Parliamentary majority suggests to vote YES. Federal Statistical Office } \\
\text { and Swissvotes Database. }\end{array}$ & 1848 & 0.7031 & 0.4569 & 0.7887 & 0.4083 & 0.6743 & 0.4687 \\
\hline $\begin{array}{l}\text { More than one } \\
\text { referendum }\end{array}$ & $\begin{array}{l}\text { Indicator variable: More than one referendum on the same day. Author construction } \\
\text { based on Swissvotes Database. }\end{array}$ & 1848 & 0.7334 & 0.4422 & 0.4718 & 0.4993 & 0.8212 & 0.3832 \\
\hline More than two referenda & $\begin{array}{l}\text { Indicator variable: More than two referenda on the same day. Author construction based } \\
\text { on Swissvotes Database. }\end{array}$ & 1848 & 0.4692 & 0.4991 & 0.2042 & 0.4032 & 0.5582 & 0.4966 \\
\hline $\begin{array}{l}\text { More than three } \\
\text { referenda }\end{array}$ & $\begin{array}{l}\text { Indicator variable: More than three referenda on the same day. Author construction } \\
\text { based on Swissvotes Database. }\end{array}$ & 1848 & 0.3001 & 0.4583 & 0.0916 & 0.2884 & 0.3701 & 0.4829 \\
\hline Low turnout referendum & $\begin{array}{l}\text { Indicator variable: Turnout in constituency is not highest when there is more than one } \\
\text { referendum on the same day (takes a value of } 0 \text { by default when there is only one } \\
\text { referendum on the same day). Author construction based on Swissvotes Database. }\end{array}$ & 1884 & 0.4822 & 0.4997 & 0.2492 & 0.4326 & 0.5466 & 0.4979 \\
\hline $\begin{array}{l}\text { Number of referenda the } \\
\text { same day }\end{array}$ & $\begin{array}{l}\text { Number of referenda on the same day. Federal Statistical Office and Swissvotes } \\
\text { Database. }\end{array}$ & 1848 & 2.8810 & 1.8827 & 2.0850 & 1.9629 & 3.1480 & 1.7768 \\
\hline Counterproposal & $\begin{array}{l}\text { Indicator variable: Referendum is a parliamentary counterproposal to an initiative. } \\
\text { Federal Statistical Office and Swissvotes Database. }\end{array}$ & 1848 & 0.0631 & 0.2432 & 0.0493 & 0.2165 & 0.0678 & 0.2514 \\
\hline Turnout & $\begin{array}{l}\text { Number of valid votes in the constituency divided by number of eligible voters. Federal } \\
\text { Statistical Office. }\end{array}$ & 1884 & 0.4615 & 0.1506 & 0.5526 & 0.1970 & 0.4363 & 0.1236 \\
\hline Government neutral & $\begin{array}{l}\text { Indicator variable: Government does not give a voting recommendation. Federal } \\
\text { Statistical Office and Swissvotes Database. }\end{array}$ & 1848 & 0.2531 & 0.4348 & 0.4577 & 0.4983 & 0.1845 & 0.3879 \\
\hline Interest groups divergent & $\begin{array}{l}\text { Indicator variable: One or more major interest groups offer divergent voting } \\
\text { recommendations. Federal Statistical Office and Swissvotes Database. }\end{array}$ & 1945 & 0.4816 & 0.4997 & & & 0.4828 & 0.4997 \\
\hline $\begin{array}{l}\text { All interest groups } \\
\text { suggest YES }\end{array}$ & $\begin{array}{l}\text { Indicator variable: All major interest groups suggest a YES vote. Federal Statistical Office } \\
\text { and Swissvotes Database. }\end{array}$ & 1945 & 0.3679 & 0.4823 & & & 0.3664 & 0.4818 \\
\hline
\end{tabular}

Notes: Unweighted descriptive statistics. Data sources indicated next to variable descriptions. 


\title{
Bundesbeschluss
}

\author{
betreffend \\ Begleitung der einer Volksabstimmung zu unterstellenden \\ Bundesgeseze oder Bundesbeschlüsse mit erläuternden \\ Botschaften.
}

Die Bundesversammlung

dersehweizerischen Eidgenossensehaft

beschließt:

Art. 1. Wenn ein Bundesgesez oder ein Bundesbeschluß nach Art. 89 der Bundesverfassung einer Volksabstimmung unterstellt wird, so soll jeweilen gleichzeitig mit dem Gesez oder Beschluß den stimmberechtigten Bürgern eine objektiv gehaltene offizielle Kundgebung uber die Gründe zugestellt werden, welche die Bundesversammlung zur Annahme des Gesezes oder Beschlusses bewogen haben.

Art. 2. In der Regel ist der Bundesrath beauftragt, diese Botschefft abzufassen und zu unterzeichnen. Immerhin kann die Bundesversammlung in getrennter Berathung der beiden Räthe bestimmen, daß sie einen Ausschuß aus ihrer Mitte beauftrage, die Botschaft zu entwerfen und zu unterzeichnen, oder sie im Einverständniß mit dem Bundesrathe auszuarbeiten und zu unterzeichnen.

Art. 3. Gegenwärtiger Beschluß tritt sofort in Wirksamkeit.

Notes: See BBI 1877 I 265, Botschaft des Bundesrathes an die hohe Bundesversammlung, betreffend die: Frage, ob Vorlagen an das Schweizervolk mit einer erläuternden Botschaft zu begleiten seien [Translate the title into English here] (14 February, 1877) provided by the Schweizerisches Bundesarchiv. 